\title{
Susceptibility of the horn fly, Haematobia irritans irritans (Diptera: Muscidae), to insecticides in Brazil
}

Suscetibilidade da mosca-dos-chifres, Haematobia irritans irritans (Diptera: Muscidae), a inseticidas no Brasil

Antonio Thadeu Medeiros Barros*; Thelma Maria Saueressig²; Alberto Gomes'; Wilson Werner Koller; John Furlong"; Eneide Santiago Girão ${ }^{5}$; Alfredo da Cunha Pinheiro ${ }^{6}$; Francisco de Paula Jardim Alves-Branco ${ }^{6}$; Maria de Fátima Munhós Sapper ${ }^{6}$; Ramayana Menezes Braga ${ }^{7}$; Amaury Apolonio de Oliveira ${ }^{8}$

${ }^{1}$ Embrapa Pantanal, Empresa Brasileira de Pesquisa Agropecuária - EMBRAPA, Corumbá, MS, Brasil

${ }^{2}$ Embrapa Cerrados, Empresa Brasileira de Pesquisa Agropecuária - EMBRAPA, Planaltina, DF, Brasil

${ }^{3}$ Embrapa Gado de Corte, Empresa Brasileira de Pesquisa Agropecuária - EMBRAPA, Campo Grande, MS, Brasil

${ }^{4}$ Embrapa Gado de Leite, Empresa Brasileira de Pesquisa Agropecuária - EMBRAPA, Juiz de Fora, MG, Brasil

${ }^{5}$ Embrapa Meio-Norte, Empresa Brasileira de Pesquisa Agropecuária - EMBRAPA, Teresina, PI, Brasil

${ }^{6}$ Embrapa Pecuária Sul, Empresa Brasileira de Pesquisa Agropecuária - EMBRAPA, Bagé, RS, Brasil

${ }^{7}$ Embrapa Roraima, Empresa Brasileira de Pesquisa Agropecuária - EMBRAPA, Boa Vista, RR, Brasil

${ }^{8}$ Embrapa Tabuleiros Costeiros, Empresa Brasileira de Pesquisa Agropecuária - EMBRAPA, Aracaju, AL, Brasil

Received August 17, 20011

Accepted March 20, 2012

\begin{abstract}
Since horn fly populations became established throughout Brazil, complaints regarding control failure have increased around the country. A broad survey to evaluate the susceptibility of horn flies to both organophosphate (OP) and pyrethroid insecticides was conducted from October 2000 to April 2003. Bioassays using filter papers impregnated with cypermethrin, permethrin or diazinon were conducted on 154 horn fly populations in 14 states and 78 municipalities. Resistance to cypermethrin, the active ingredient present in most insecticide products for horn fly control in Brazil, was detected in $98.46 \%$ of the populations, with resistance ratios (RR) ranging from 2.5 to 719.9 . Resistance to permethrin (RRs $\leq 6.3$ ) was found in $96.67 \%$ of the populations, despite its lack of use. In general, pyrethroid resistance was detected in $97.18 \%$ of the horn fly populations, with frequencies greater than $87 \%$ in all regions of the country. The status of susceptibility of horn fly populations in Brazil to insecticides can be characterized by high susceptibility to OPs and widespread resistance to pyrethroids, potentially compromising the efficacy of pyrethroid products in most cases. Although some partial results have previously been presented, a general picture of horn fly susceptibility in Brazil is presented here for the first time.
\end{abstract}

Keywords: Horn flies, pyrethroid resistance, parasite resistance.

\section{Resumo}

Desde a dispersão da mosca-dos-chifres, no Brasil, queixas sobre seu controle aumentaram em todo o país. Um amplo levantamento objetivando avaliar a suscetibilidade da mosca a inseticidas organofosforados (OF) e piretróides foi realizado de outubro de 2000 a abril de 2003. Bioensaios com papéis de filtro impregnados com cipermetrina, permetrina ou diazinon foram conduzidos em 154 populaçóes da mosca-dos-chifres de 14 Estados e 78 municípios. Resistência à cipermetrina, ingrediente ativo presente na maioria dos produtos para controle da mosca-dos-chifres no Brasil, foi detectada em $98,46 \%$ das populaçôes, com fatores de resistência (FR) variando de 2,5 a 719,9. Resistência à permetrina ( $\mathrm{FR} \leq 6,3)$ foi encontrada em $96,67 \%$ das populaçóes testadas, apesar da falta de uso de produtos contendo este princípio ativo. Em geral, resistência a piretróides foi detectada em 97,18\% das populaçóes, com frequências acima de $87 \%$ em todas as regiôes do país. A situação da suscetibilidade da mosca-dos-chifres a inseticidas, no Brasil, pode ser caracterizada por uma elevada suscetibilidade aos organofosforados e ocorrência generalizada de resistência aos piretróides, potencialmente comprometendo a eficácia desses produtos na maioria dos casos. Embora resultados parciais tenham sido apresentados anteriormente, um quadro geral da suscetibilidade da mosca-dos-chifres no Brasil é apresentado pela primeira vez.

Palavras-chave: Mosca-dos-chifres, resistência a piretróides, resistência parasitária.

\footnotetext{
${ }^{*}$ Corresponding author: Antonio Thadeu Medeiros Barros

Embrapa Pantanal, Empresa Brasileira de Pesquisa Agropecuária - EMBRAPA,

Rua 21 de Setembro, 1880, CEP 79320-900, Corumbá, MS, Brasil

e-mail: thadeu@cpap.embrapa.br
} 


\section{Introduction}

In view of the increasing numbers of suspected cases of horn fly resistance in Brazil and limited knowledge regarding its status in this country, a comprehensive survey was started in 2000 to evaluate the susceptibility of horn fly populations to pyrethroid and organophosphate (OP) insecticides throughout Brazil. Partial results from that study for some states have been presented in technical publications (BRAGA; BARROS, 2003; BRAGA; BARROS, 2004; SAUERESSIG; BARROS, 2003) and in scientific papers (BARROS et al., 2002; OLIVEIRA et al., 2006; BARROS et al., 2007). However, complete data from around the country are presented here for the first time, providing a general picture of the status of horn fly susceptibility to insecticides, in Brazil at the beginning of this century.

In the early 1980s, the horn fly, Haematobia irritans irritans, was officially reported in northern Brazil for the first time (VALÉRIO; GUIMARÁES, 1983). After crossing the rainforest and the Amazon river, $H$. irritans quickly dispersed throughout the country within a few years, facilitated by cattle transportation, and soon it was ranked among the major livestock pests because of the economic losses inflicted on the cattle industry (GRISI et al., 2002).

Following the gradual dispersal of horn flies in Brazil, chemical control became necessary. Because of the lack of insecticidal products for this pest on the Brazilian market, horn fly control initially relied on products for cattle tick control, consisting mostly of pyrethroids. Commercial products quickly became available for horn fly control, but selection pressure remained mostly with pyrethroids.

Horn fly populations were highly susceptible to both pyrethroid and OP products until the mid-1990s, as shown in several studies on product efficacy (CAMPOS PEREIRA et al., 1992, 1994; GRISI; SCOTT, 1992). However, complaints regarding lower product efficacy and control failure soon started to be made from around the country, and pyrethroid resistance was eventually confirmed (GUGLIELMONE et al., 2001).

\section{Material and Methods}

A large-scale field survey on susceptibility of horn fly populations to pyrethroid and OP insecticides was conducted from October 2000 to April 2003 in Brazil, by eight research centers belonging to the Brazilian Agricultural Research Corporation (Embrapa). The geographical regions (abbreviations for state names in parentheses) covered by these field teams were: a) Central-Western region: Embrapa Pantanal (MS, MT), Embrapa Beef Cattle (MS, MT) and Embrapa Cerrados (GO, DF, TO); b) Southeastern region: Embrapa Dairy Cattle (ES, MG, RJ); c) Southern region: Embrapa South Animal Husbandry and Sheep (RS); d) Northeastern region: Embrapa Coastal Tablelands (AL, BA, SE) and Embrapa Mid-North (MA, PI); and e) Northern region: Embrapa Roraima (RR).

Training on the bioassay technique was provided to team leaders prior to field activities. The initial selection of states and municipalities for conducting bioassays depended on the geographical coverage by each field team. The random selection of ranches for bioassays was based on operational factors (ease of access, willingness of owner to collaborate with the study, fly availability, etc.), rather than suspected insecticide resistance. There was no effort to select animal breeds, production systems, history of insecticide use, or any other particular situation; in fact, all sorts of situations were encountered during the fieldwork, which was carried out in very distinct regions of the country.

During visit planning prior to field trips, ranch owners were asked to keep a cattle herd untreated for at least two weeks before the visit. It was assumed that this procedure had been complied with, unless local information or high mortality in the fly control group during the bioassays led to suspicion of recent cattle treatment with insecticides.

The susceptibility of field horn fly populations to insecticides was assessed by bioassays using impregnated filter paper (SHEPPARD; HINKLE, 1987; BARROS et al., 2002). In order to standardize laboratory procedures, the insecticide kits used in the bioassays were produced in the Entomology Laboratory of Embrapa Pantanal and later distributed to all collaborators. The technical-grade insecticides used in the bioassays were diazinon ( $>93.5 \%$ purity, provided by Novartis and Chem Service), permethrin ( $>97 \%$ purity, FMC do Brasil and Chem Service) and cypermethrin (92\%, Minerthal) diluted in acetone. Each insecticide kit contained three replicates of eight to ten concentrations of permethrin $\left(0.4-51.2 \mu \mathrm{g} . \mathrm{cm}^{-2}\right)$, cypermethrin $\left(1.6-819.2 \mu \mathrm{g} . \mathrm{cm}^{-2}\right)$ or diazinon $\left(0.1-3.2 \mu \mathrm{g} . \mathrm{cm}^{-2}\right)$. Control filter papers were treated only with acetone (Merck P.A.). The impregnated filter papers were kept in aluminum foil packs under refrigeration until they were placed in plastic disposable Petri dishes $(90 \mathrm{~mm}$ in diameter) just before the field trips.

Bioassays with permethrin were mostly conducted in 2000 , with a few in 2001 and none in the following years. Cypermethrin replaced permethrin in bioassays from 2001 onwards. Diazinon bioassays were performed in all years.

Insecticide kits were loaded immediately after an adequate number of flies had been collected from cattle by using entomological hand nets. Not all insecticide bioassays were performed at each site, and this depended on fly availability. Fly mortality was assessed after two hours of exposure, and flies that were unable to walk were considered dead. Bioassay mortality data from three replications were pooled and analyzed by means of probit analysis using POLO-PC (LEORA SOFTWARE, 1987) to obtain the lethal concentration $\left(\mathrm{LC}_{50}\right)$ for each field population.

Every year, the insecticide kits produced were tested on the susceptible horn fly colony that is maintained at the USDA Knipling-Bushland US Livestock Insects Research Laboratory (Kerrville, TX, USA), to provide a reference $\mathrm{LC}_{50}$. Resistance ratios (RRs) were calculated by dividing the $\mathrm{LC}_{50}$ from field populations by the $\mathrm{LC}_{50}$ from the reference susceptible colony. Differences in $\mathrm{LC}_{50}$ between field and colony populations were considered statistically significant (field populations considered to be resistant) when the $95 \%$ fiducial limits did not overlap. Bioassays with fly mortality $>10 \%$ in control dishes or without showing fiducial limits in the probit analysis were not used in this paper.

Because the RRs for permethrin were relatively low and small changes in the $\mathrm{LC}_{50}$ might make resistance undetectable through standard evaluation of $\mathrm{LC}_{50}$ fiducial limits, the analysis on susceptibility to this insecticide also took into consideration fly 
survival at diagnostic concentrations (DCs) in field bioassays. The permethrin DCs were the lowest concentration from each kit that resulted in $100 \%$ mortality of flies from the susceptible colony after two hours of exposure. Thus, flies surviving at a DC were considered resistant. The DCs for the 2000 and 2001 permethrin kits were 6.4 and $1.6 \mu$ g. $\mathrm{cm}^{-2}$, respectively. Horn fly populations showing $1 \%$ or less survival were considered effectively susceptible (DAVIDSON; ZAHAR, 1973; MAY; DOBSON, 1986), while higher frequencies were considered indicative of resistance in the population.

A standard questionnaire on ectoparasite control was administered at every ranch where bioassays were performed, in order to obtain specific information about the history of insecticide use and cattle pest control practices. However, these data will be not presented in this article.

\section{Results and Discussion}

A total of 251 insecticide bioassays using permethrin (90), cypermethrin (65) and diazinon (96) were conducted at 154 cattle ranches located in 78 municipalities of 14 states, in all major regions of Brazil (Table 1). Most of the bioassays were conducted in the Central-Western region (Figure 1), which is the most important beef cattle production area of the country, representing more than one-third of the national cattle herd over the last decade (IBGE, 2010).

Variations in insecticide kits occur in long-term studies due to several technical factors, thus making RR more appropriate than $\mathrm{LC}_{50}$ for comparing results among different kits (SHEPPARD; JOYCE, 1992). For this reason, the data from this survey are discussed based on RRs.
The general status of insecticide susceptibility was similar among horn fly populations even from very distinct regions, which provided a consistent picture regarding the status of insecticide resistance in this country.

Permethrin resistance based on $\mathrm{LC}_{50}$ was detected in $67.78 \%$ of the populations and resulted in RRs of less than 6.4, and lower than 3 in most $(75.56 \%)$ resistant populations. These relatively low RRs may suggest apparent susceptibility or incipient resistance to pyrethroids in these populations. However, permethrin RRs of around 3 to 4 have previously been associated with pyrethroid ear tag failure (KUNZ; SCHMIDT, 1985; FOIL et al., 2005). Thus, about one-fourth of the cattle ranches in the present study could be facing problems in their efforts to control horn flies with pyrethroid products if permethrin bioassays were considered to be good indicators of pyrethroid susceptibility in those situations.

Because minor changes in the $\mathrm{LC}_{50}$ make resistance detection difficult, use of discriminatory concentrations may be a more suitable approach (DAVIDSON; ZAHAR, 1973). In fact, analysis on data from diagnostic concentrations detected resistance to permethrin in $96.67 \%$ of the tested populations. Flies survived twice the permethrin DC for 2 hours or even longer in most populations with survival rates greater than $1 \%$, while no fly survived higher concentrations or longer exposures when the frequency of resistant individuals was lower than 1\% (BARROS et al., 2007). Molecular analysis on some of these sampled populations confirmed that $k d r$ (knockdown resistance) pyrethroid-resistant flies (SABATINI et al., 2009) were present in populations with permethrin RR as low as 1.5 .

Although presence of flies surviving a given DC may indicate resistance development in a population, it should not be directly associated with control failure unless correlation between bioassay

Table 1. Geographical range of the survey on horn fly susceptibility to insecticides conducted in Brazil from 2000 to 2003.

\begin{tabular}{|c|c|c|c|c|}
\hline Region & State & & Municipality & Site \\
\hline \multirow{3}{*}{ Central-Western } & $\mathrm{GO} / \mathrm{DF}^{1}$ & 7 & $\begin{array}{l}\text { Água Fria de Goiás, Aragarças, Brasília, Campos Belos, Carmo do Rio Verde, Cristalina, } \\
\text { São João d'Aliança }\end{array}$ & 10 \\
\hline & $\mathrm{MS}^{2,3}$ & 15 & $\begin{array}{l}\text { Aquidauana, Bela Vista, Campo Grande, Corumbá, Ladário, Miranda, Mundo Novo, } \\
\text { Paranaíba, Porto Murtinho, Rio Negro, Rochedo, São Gabriel do Oeste, Sidrolândia, } \\
\text { Terenos, Três Lagoas }\end{array}$ & 40 \\
\hline & $\mathrm{MT}^{2}$ & 11 & $\begin{array}{l}\text { Barão de Melgaço, Barra do Garças, Cáceres, Cuiabá, Lambari d’Oeste, Poconé, Pontal } \\
\text { do Araguaia, Rondonópolis, Salto do Céu, Santo Antônio do Leverger, Várzea Grande }\end{array}$ & 18 \\
\hline \multirow{4}{*}{ Northeastern } & $\mathrm{BA}^{4}$ & 2 & Capela do Alto Alegre, Pé de Serra & 3 \\
\hline & MA & 3 & Bacabal, Lagoa do Mato, Santa Inês & 7 \\
\hline & PI & 1 & Teresina & 1 \\
\hline & $\mathrm{SE}^{4}$ & 8 & $\begin{array}{l}\text { Capela, Feira Nova, Frei Paulo, Lagarto, Laranjeiras, Nossa Senhora das Dores, Riacháo } \\
\text { do Dantas, Simáo Dias }\end{array}$ & 15 \\
\hline Southeastern & RJ & 3 & Itaguaí, Quatís, Seropédica & 4 \\
\hline Southern & RS & 13 & $\begin{array}{l}\text { Alegrete, Bagé, Dom Pedrito, Hulha Negra, Jaguarão, Lavras do Sul, Pedras Altas, } \\
\text { Quaraí, Rio Grande, Rosário do Sul, Santana da Boa Vista, Santana do Livramento, São } \\
\text { Gabriel }\end{array}$ & 17 \\
\hline Total & 14 & 78 & & 154 \\
\hline
\end{tabular}




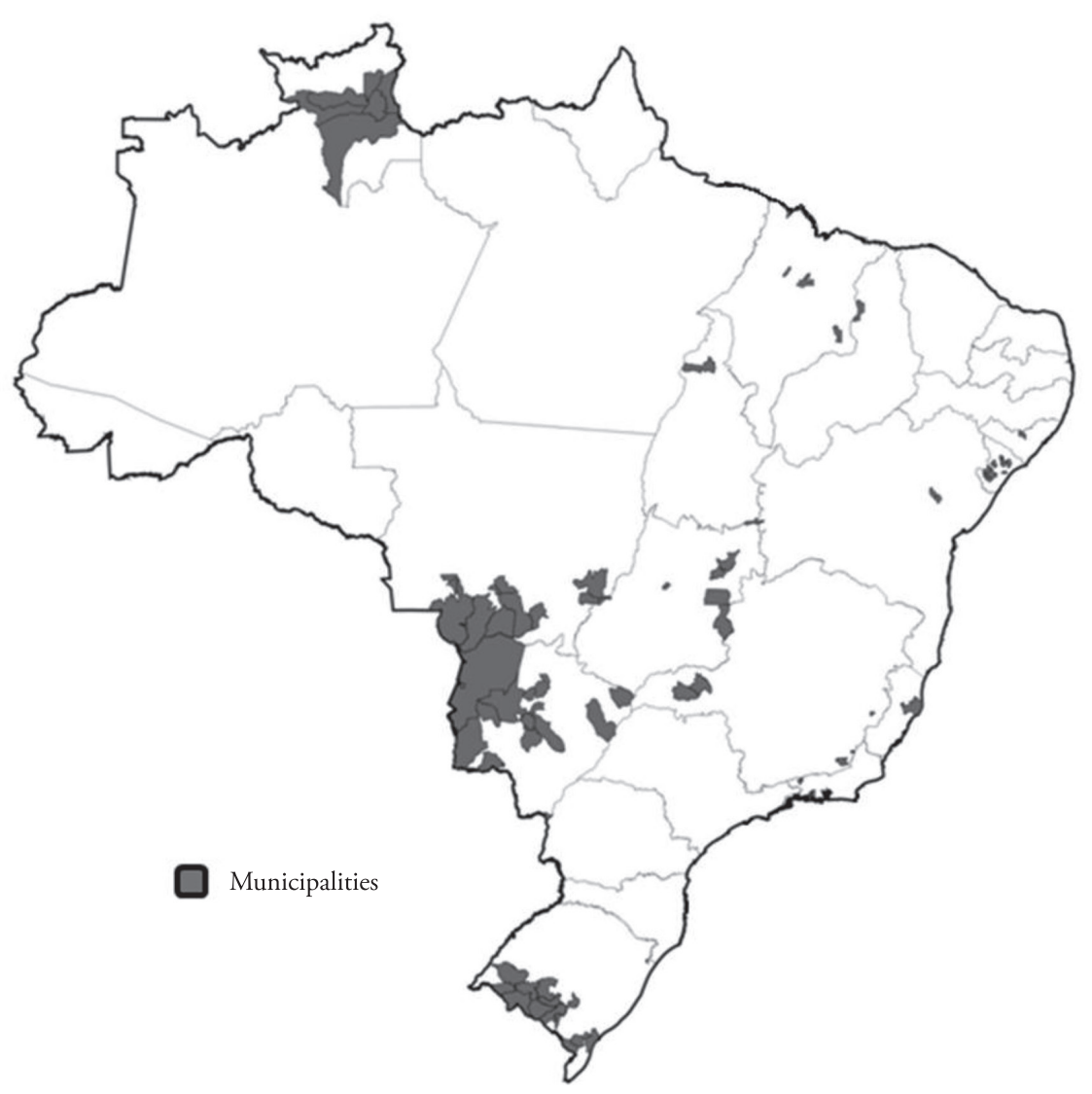

Figure 1. Survey on horn fly susceptibility to insecticides in Brazil (2000-2003).

data and product efficacy has previously been established. Not only does effective resistance depend on several factors (e.g. frequency of resistant flies in the population), but also the results from artificial bioassays using active ingredients and exposure to insecticide products that are applied to cattle may be quite different, thus producing misleading conclusions on how effective a certain insecticide concentration may be under field conditions. Therefore, even populations showing some resistant individuals in bioassays may still show considerable susceptibility in practice. Ultimately, detection of resistant flies in bioassays indicates that even if reduced product efficacy is still not perceptible, effective resistance is on its way and control impairment will emerge if selective pressure persists.

Studies correlating bioassay results and insecticide efficacy have shown that a 5\% horn fly survival rate at an OP diagnostic concentration was associated with reduction of OP ear tag efficacy in the field (BARROS et al., 2001). If this criterion (5\% frequency of resistant flies in a DC) can be extrapolated as an indicator for potential pyrethroid failure, then approximately $84 \%$ of the fly populations in this study would present control problems if pyrethroid products were used.

After the first year of this study, it became obvious that cypermethrin was the insecticide most used among cattle producers and the primary selective agent behind the horn fly pyrethroid resistance detected around the country. Pilot bioassays using cypermethrin provided much higher RRs, which made interpretation easier and more conclusive, and thus permethrin was replaced with cypermethrin in subsequent bioassays in this study. Comparison between the results from pyrethroid bioassays indicated that whenever possible, the insecticide to be chosen for bioassays evaluating susceptibility in field populations should be the most widely used insecticide in the region, which ultimately represents the primary selective agent in each particular situation.

Resistance to cypermethrin was detected in $98.46 \%$ of the populations and the respective RRs ranged from 2.5 to 719.9 , thus establishing that high levels of resistance to this pyrethroid were occurring throughout the country (Table 2). The frequency of resistance to cypermethrin found among the fly populations $(98.46 \%)$ was very similar to that detected by permethrin DC (96.67\%). High frequency of resistance to cypermethrin has also been detected in neighboring countries, such as Argentina, where resistance was found in $93.83 \%$ of the horn fly populations, with RRs ranging from 26 to 3,560 (GUGLIELMONE et al., 2001).

High levels of resistance to pyrethroids are not uncommon and can reach thousands-fold (SHEPPARD; JOYCE, 1992). However, much lower RRs can actually be associated with product failure in the field, as shown by the reduced efficacy of a cypermethrin pour-on product applied to a population with cypermethrin RRs < 34 (GUGLIELMONE et al., 1998). In the present study, $73.85 \%$ of the fly populations exposed to cypermethrin bioassays showed RRs $\geq 35$, which suggests that about three out of four of the populations were potentially facing problems regarding horn fly control, as is routinely reported by cattlemen. 
Table 2. Profile of horn fly susceptibility based on insecticide bioassays conducted in Brazil from October 2000 to April 2003.

\begin{tabular}{|c|c|c|c|c|c|c|}
\hline \multirow{2}{*}{$\begin{array}{c}\text { Region/ } \\
\text { State }\end{array}$} & \multirow{2}{*}{$\begin{array}{c}\text { Number of } \\
\text { sites }\end{array}$} & \multirow{2}{*}{$\begin{array}{l}\text { Number of } \\
\text { bioassays }\end{array}$} & \multicolumn{3}{|c|}{ Resistance ratio $(\mathrm{RR})^{\mathrm{a}}$} & \multirow{2}{*}{$\begin{array}{c}\text { FPR }^{b} \\
(\%)\end{array}$} \\
\hline & & & Permethrin & Cypermethrin & Diazinon & \\
\hline Central-Western & 68 & 113 & & & & 98.48 \\
\hline $\mathrm{GO} / \mathrm{DF}^{1}$ & 10 & 16 & $1.4-1.9$ & $20.4-135.9$ & $0.2-0.8$ & 100.0 \\
\hline $\mathrm{MS}^{2,3}$ & 40 & 65 & $0.6-4.2$ & $27.6-90.3$ & $0.1-1.1$ & 97.5 \\
\hline $\mathrm{MT}^{2}$ & 18 & 32 & $0.6-3.1$ & $35.6-98.1$ & $0.1-0.5$ & 100.0 \\
\hline Northeastern & 31 & 53 & & & & 100.00 \\
\hline MA & 7 & 13 & $1.1-3.7$ & $58.9-65.0$ & $0.1-0.7$ & 100.0 \\
\hline PI & 1 & 2 & - & 38.3 & 0.1 & 100.0 \\
\hline $\mathrm{SE}^{4}$ & 15 & 24 & $2.5-5.9$ & $21.7-719.9$ & $0.1-1.2$ & 100.0 \\
\hline Northern & 20 & 32 & & & & 94.12 \\
\hline $\mathrm{RR}^{5,6}$ & 18 & 29 & $1.2-1.6$ & $2.5-105.9$ & $0.1-0.5$ & 93.3 \\
\hline MG & 12 & 16 & $3.5-6.3$ & $28.1-152.8$ & $0.2-0.5$ & 100.0 \\
\hline RJ & 4 & 8 & - & $16.5-255.6$ & $0.1-0.3$ & 100.0 \\
\hline Southern & 17 & 27 & & & & 87.50 \\
\hline RS & 17 & 27 & $0.5-4.2$ & 24.3 & 0.1-1.0 & 87.5 \\
\hline Total & 154 & 251 & $0.5-6.3$ & $2.5-719.9$ & 0.1-1.2 & 97.18 \\
\hline
\end{tabular}

${ }^{a} \mathrm{RR}$ range in each state $\left(\mathrm{RR}=\mathrm{LC}_{50-2 \mathrm{~h}}\right.$ field population/LC $\mathrm{LC}_{50-2 \mathrm{~h}}$ susceptible colony) ${ }^{\mathrm{b}}$ Frequency of pyrethroid resistance in each state or region (FPR $=\%$ of resistant populations in the total tested). Not all fly populations were bioassayed with both pyrethroids; populations were considered to be pyrethroid-resistant when analysis of either permethrin or cypermethrin bioassay data led to this conclusion. ${ }^{1-6}$ Locations from where partial results from this study have previously been published:

${ }^{1}$ Saueressig and Barros (2003), ${ }^{2}$ Barros et al. (2002), ${ }^{3}$ Barros et al. (2007), ${ }^{4}$ Oliveira et al. (2006), ${ }^{5,6}$ Braga and Barros (2003, 2004).

Cypermethrin resistance was detected in most populations in the Northern region (91.67\%) and in virtually all populations in all other regions of the country. Most of the highest cypermethrin RRs were found in the Northeastern states, where control of horn flies has relied mainly on pyrethroid products: mostly cypermethrin $(88.46 \%)$ and deltamethrin $(80.77 \%)$, usually applied by manual backpack spraying (OLIVEIRA et al., 2006). In the Central-Western region, where cattle are raised extensively and parasite management practices are often not adopted, cypermethrin RR was lower than 100 (except for one population), thus indicating that selection pressure toward resistance was lower than observed in other regions of the country but still high enough to impair control.

In general, considering bioassays with both pyrethroids, resistance to this insecticide class was detected in $97.18 \%$ of the populations. Pyrethroid resistance occurred in all the surveyed states and in all but one municipality (São Gabriel, RS), where a single ranch was sampled. The frequency of pyrethroid resistance was very high, irrespective of the state or region (Table 2). The lowest frequency of resistance to pyrethroids found in any state $(87.50 \%$ in the state of Rio Grande do Sul) illustrates the magnitude of the problem as a whole. All the populations in the Northeastern and Southeastern regions were resistant to at least one of the pyrethroids tested, but the resistance frequency was also very high in the Central-Western (98.48\%) and Northern (94.12\%) regions.

Susceptibility of Brazilian horn fly populations to pyrethroids has dramatically changed in the last decade, in comparison with the initial records (SCOTT et al., 1994). The status of pyrethroid resistance in Brazil is similar to what has been observed in other
South American countries, such as Uruguay (MARQUES et al., 1997), Argentina (GUGLIELMONE et al., 2001) and Chile (OYARZÚN et al., 2011), where widespread horn fly resistance to pyrethroids has been detected regionally or nationally.

Independent of geographical location, remarkable variation in resistance levels to pyrethroids between populations that were sometimes just a few kilometers apart were observed. Ultimately, this reflected the previous history of pesticide use and control practices adopted locally, which are of paramount importance regarding resistance development (GEORGHIOU; TAYLOR, 1986). Overall, the levels of population resistance tended to be more closely associated with the extent of the management practices adopted at the sites, and thus, higher levels of resistance were most often detected in more developed production systems.

Several combined factors may have predisposed and/or contributed towards the fast build-up and spread of pyrethroid resistance, as well as the magnitude that it has reached around the country. Development of pyrethroid resistance in horn flies can be quite a fast phenomenon and may take just 20-30 generations (BYFORD et al., 1999) or 3-4 years to reach perceptible levels. In Brazil, horn flies may produce about 20 generations per year (BARROS, 2002; RODRIGUES; MARCHINI, 2001), thus making development of resistance a fast process if favorable selection pressure is imposed on the population. Moreover, pyrethroid products have dominated the national market for bovine ectoparasiticide products (SINDAN, 2001, 2003) since before the horn fly entered the country. They were the first choice for horn fly control and have been the major agent selecting for resistance. Furthermore, the initial pyrethroid products used in horn fly control were 
actually for use in controlling cattle ticks and were at twice the concentration needed for horn fly control. Finally, excessive and inappropriate use of insecticide/acaricide products has been a common practice on cattle ranches in Brazil, thus playing a role in accelerating development of horn fly resistance to pyrethroids.

Therefore, the status of pyrethroid resistance has resulted from at least a decade of the combination of all these biological and operational factors together. Although pyrethroid resistance has been a major complaint among producers for some time, the higher toxicity of other insecticides (OPs) as well as higher prices of products from newer classes (e.g. macrocyclic lactones or phenylpyrazoles) and more expensive formulations (e.g. pour-on and ear tags) have helped to maintain sprayed pyrethroid products as the primary control choice. Traditional horn fly control (as well as current tick control) based on large-scale use of pyrethroid products is not sustainable and no longer satisfactory, and producers are looking for viable alternatives.

The horn fly populations showed high susceptibility to diazinon in all regions of the country; bioassays with this OP provided RRs $<1.3$ (Table 2). Previous studies in South American countries also failed to detect resistance to diazinon (MARQUES et al., 1997; GUGLIELMONE et al., 2000; BARROS et al., 2002; OYARZÚN et al., 2011), thus suggesting that if it is occurring, it either must be still at a low frequency or must be confined to particular sites. So far, horn fly resistance to OPs has been reported only in the USA (CILEK et al., 1991; STEELMAN et al., 1994; BARROS et al., 2001) and Mexico (GARCÍA et al., 2004).

In this study, most of the wild fly populations showed higher susceptibility to diazinon than did the flies in the susceptible colony. Such negative cross-resistance has previously been reported in horn fly pyrethroid-resistant populations (SHEPPARD; MARCHIONDO, 1987; CROSBY et al., 1991), caused by increased diazinon activation by the mixed function oxidases (MFOs) that are present in pyrethroid-resistant flies (CILEK et al. 1995). In fact, MFOs play the most important role in horn fly pyrethroid resistance in Brazil (ATM Barros, unpublished data), although $k d r$ has been detected at low frequencies in pyrethroid-resistant populations (GUERRERO; BARROS, 2006; SABATINI et al., 2009). The relatively low use of OP products for controlling horn flies, as well as the widespread pyrethroid resistance mainly due to oxidative metabolism, may explain the high OP susceptibility.

Unfortunately, initial high efficacy of a product and effective control of horn flies do not necessarily mean that the resistance management strategy is appropriate for a long-term approach. After at least one decade of chemical control based mostly on pyrethroid products, this large-scale study indicates that there is widespread pyrethroid resistance in horn fly populations all over Brazil. Insecticide resistance has become a national concern and a critical routine problem for cattle producers in all regions. Inadequate control practices adopted by ranchers, as well as a market dominated by pyrethroid products, have predisposed towards resistance and continue to aggravate the current situation.

Furthermore, because of the broad action of most pesticide products, control over a livestock pest tends to affect untargeted species that share the same host or even its excrement. Thus, resistance in a target species tends to influence not only control over that species but also resistance development in other species, which seems to be the case between the horn fly and the cattle tick [Rhipicephalus (Boophilus) microplus]. This side effect of horn fly resistance may become a particularly important issue in regions where cattle ticks and tick-borne diseases are major problems affecting the cattle industry.

The present field survey confirms the susceptibility of horn flies to OPs, as well as establishing the widespread extent of horn fly pyrethroid resistance in Brazil. It thus provides baseline information for future horn fly studies and control strategies, as well as for resistance management programs, with the aim of reducing the negative impact of horn flies on the cattle industry in the country.

\section{Acknowledgements}

We wish to thank the numerous people who participated in the huge work carried out in the field all over the country, as well as the ranch owners. It would be impossible to list them all. We are also grateful to Empresa Brasileira de Pesquisa Agropecuária (Embrapa) and Fundação de Apoio ao Desenvolvimento do Ensino, Ciência e Tecnologia do Estado de Mato Grosso do Sul (Fundect) for supporting the study; to Novartis, FMC do Brasil, and Minerthal for providing technical insecticides; to Knipling-Bushland US LIRL for supplying insecticide-susceptible flies; and to Lane Foil (Louisiana State University) and Felix Guerrero and Andrew Li (USDA, Kerrville) for conducting bioassays on susceptible flies.

\section{References}

Barros ATM. Desenvolvimento de Haematobia irritans em massas fecais de bovinos mantidas em laboratório. Pesq Agropec Bras 2002; 37(2): 217-221.

Barros ATM, Gomes A, Koller WW. Insecticide susceptibility of horn flies, Haematobia irritans (Diptera : Muscidae), in the state of Mato Grosso do Sul, Brazil. Rev Bras Parasitol Vet 2007; 16(3): 145-151. http:// dx.doi.org/10.1590/S1984-29612007000300006

Barros ATM, Gomes A, Ismael APK, Koller WW. Susceptibility to diazinon in populations of the horn fly, Haematobia irritans (Diptera: Muscidae), in Central Brazil. Mem Inst Oswaldo Cruz 2002; 97(6): 905-907. http:// dx.doi.org/10.1590/S0074-02762002000600029

Barros ATM, Ottea J, Sanson D, Foil LD. Horn fly (Diptera: Muscidae) resistance to organophosphate insecticides. Vet Parasitol 2001; 96(3): 243-256. http://dx.doi.org/10.1016/S0304-4017(00)00435-0

Braga RM, Barros ATM. Avaliação da susceptibilidade da mosca dos chifres (Haematobia irritans) a inseticida da classe dos piretróides em Roraima. Boa Vista: Embrapa Roraima; 2003. 6 p. (Embrapa Roraima, Comunicado Técnico, n. 10). [cited 2011 Nov. 03]. Available from: http://www.cpafrr. embrapa.br/embrapa/attachments/787_cot01003_mosca_ramayana.pdf.

Braga RM, Barros ATM. Avaliação da susceptibilidade da mosca dos chifres, Haematobia irritans (Diptera:Muscidae) a inseticida da classe dos organofosforados (diazinon) em Roraima. Boa Vista: Embrapa Roraima; 2004. 6 p. (Embrapa Roraima, Comunicado Técnico, n. 6). [cited 2011 Nov. 03]. Available from: http://www.cpafrr.embrapa.br/ embrapa/attachments/788_cot00604_mosca_ramayana.pdf. 
Byford RL, Craig ME, DeRouen SM, Kimball MD, Morrison DG, Wyatt WE, et al. Influence of permethrin, diazinon and ivermectin treatments on insecticide resistance in the horn fly (Diptera: Muscidae). Int J Parasitol 1999; 29(1): 125-135. http://dx.doi.org/10.1016/ S0020-7519(98)00196-9

Campos Pereira M, Vieira-Bressan MCR, Cossi Junior O. Field trial to assess the efficacy of insecticides for the control of horn flies on pastured beef cattle in Brazil. Rev Bras Parasitol Vet 1992; 1(1): 41-43.

Campos Pereira M, Cossi Junior O, Dias AMS. Efficacy of some insecticides for control of the horn fly. Braz J Anim Res Anim Sci 1994; 31(3-4): 186-190.

Cilek JE, Steelman CD, Knapp FW. Horn fly (Diptera: Muscidae) insecticide resistance in Kentucky and Arkansas. J Econ Entomol 1991; 84(3): 756-762. PMid:1885841.

Cilek JE, Dahlman DL, Knapp FW. Possible mechanism of diazinon negative cross-resistance in pyrethroid-resistant horn flies (Diptera: Muscidae). J Econ Entomol 1995; 88(3): 520-524.

Crosby BL, Byford RL, Kinzer HG. Insecticide resistance in the horn fly, Haematobia irritans (L.), in New Mexico: survey and control. Southwest Entomol 1991; 16(4): 301-309.

Davidson G, Zahar AR. The practical implications of resistance of malaria vectors to insecticides. Bull World Health Org 1973; 49(5): 475-483. PMid:4547328 PMCid:2480992.

Foil LD, Guerrero F, Alison MW, Kimball MD. Association of the $k d r$ and superkdr sodium channel mutations with resistance to pyrethroids in Louisiana populations of the horn fly, Haematobia irritans irritans (L.). Vet Parasitol 2005; 129(1-2): 149-158. PMid:15817215. http://dx.doi. org/10.1016/j.vetpar.2005.01.007

García CA, Covarruvias AC, Flores AV, Vázquez ZG, Kunz S, Ledezma AM. Horn fly (Haematobia irritans) resistance to cypermethrin and diazinon in the state of Tamaulipas, Mexico: current situation. Vet Mex 2004; 35(3): 237-244.

Georghiou GP, Taylor CE. Factors influencing the evolution of resistance. In: Committee on Strategies for the Management of Pesticide Resistant Pest Populations, National Research Council. Pesticide resistance: strategies and tactics for management. Washington: National Academy Press; 1986. p. 157-169.

Grisi L, Scott FB. Suceptibilidade de populações da mosca-dos-chifres (Haematobia irritans) a inseticidas no estado de São Paulo. Hora Vet 1992; 65: 11-12.

Grisi L, Massard CL, Moya Borja GE, Pereira JB. Impacto econômico das principais ectoparasitoses em bovinos no Brasil. Hora Vet 2002; 125: 8-10.

Guerrero FD, Barros ATM. Role of $k d r$ and esterase-mediated metabolism in pyrethroid-resistant populations of Haematobia irritans irritans (Diptera: Muscidae) in Brazil. J Med Entomol 2006; 43(5): 896-901. http://dx.doi. org/10.1603/0022-2585(2006)43[896:ROKAEM]2.0.CO;2

Guglielmone AA, Kunz SE, Castelli ME, Volpogni MM, Kammalah D, Martins JR, et al. Susceptibilidad al diazinón de la Haematobia irritans (Diptera: Muscidade) de diferentes localidades argentinas y del sur de Brasil. Rev Med Vet 2000; 91: 184-186.

Guglielmone AA, Kunz SE, Volpogni MM, Anziani OS, Flores SG. Diagnóstico de poblaciones de la Haematobia irritans (Diptera: Muscidade) resistentes a la cipermetrina en Santa Fe, Argentina. Rev Med Vet 1998; 79: 353-356.
Guglielmone AA, Castelli ME, Volpogni MM, Medus PD, Martins JR, Suárez VH, et al. Toxicity of cypermethrin and diazinon to Haematobia irritans (Diptera: Muscidae) in its American southern range. Vet Parasitol 2001; 101(1): 67-73. http://dx.doi.org/10.1016/ S0304-4017(01)00490-3

Instituto Brasileiro de Geografia e Estatística - IBGE. Sistema IBGE de Recuperação Automática - SIDRA. Efetivo do Rebanho Bovino [online]. 2010. [cited 2011 Mar. 04]. Available from: http://www.sidra. ibge.gov.br/bda/pecua/default.asp.

Kunz SE, Schmidt CD. The pyrethroid resistance problem in the horn fly. J Agric Entomol 1985; 2(4): 358-363.

Leora Software. POLO-PC a User's Guide to Probit or Logit Analysis. Berkeley: LeOra Software; 1987.

Marques L, Moon R, Cardozo H, Cuore U, Trelles A, Bordaberry S. Primer diagnóstico de resistencia de Haematobia irritans (Diptera: Muscidae) en Uruguay. Determinación de susceptibilidad a cypermetrina y diazinón. Vet (Uruguay) 1997; 33(133): 20-23.

May RM, Dobson AP. Population dynamics and the rate of evolution of pesticide resistance. In: Committee on Strategies for the Management of Pesticide Resistant Pest Populations, National Research Council. Pesticide Resistance: strategies and tactics for management. Washington: National Academy Press; 1986. p. 170-193.

Oliveira AA, Azevedo HC, Melo CB, Barros ATM. Suscetibilidade da mosca-dos-chifres (Haematobia irritans) a inseticidas nos tabuleiros costeiros de Alagoas, Bahia e Sergipe. Rev Bras Parasitol Vet 2006; 15(2): 65-70. PMid:16834898.

Oyarzún MP, Li AY, Figueroa CC. High levels of insecticide resistance in introduced horn fly (Diptera: Muscidae) populations and implications for management. J Econ Entomol 2011; 104(1): 258-265. http://dx.doi. org/10.1603/EC10188

Rodrigues SR, Marchini LC. Estudo de temperaturas em massas fecais de bovinos e previsão do número de geraçóes anuais de Haematobia irritans (Diptera, Muscidae), em Piracicaba, SP, Brasil. Rev Bras Entomol 2001; 45(2): 89-94.

Sindicato Nacional da Indústria de Produtos de Saúde Animal - SINDAN. Manual de Produtos Veterinários 2001 - 2002. 3rd ed. Robe Editorial; 2001.

Sindicato Nacional da Indústria de Produtos de Saúde Animal - SINDAN. Manual de Produtos Veterinários 2003 - 2004. 4th ed. Robe Editorial; 2003.

Sabatini GA, Ribolla PEM, Barros ATM, Guerrero FD, Schumaker TTS. Knockdown resistance in pyrethroid-resistant horn fly (Diptera: Muscidae) populations in Brazil. Rev Bras Parasitol Vet 2009; 18(3): 8-14. http://dx.doi.org/10.4322/rbpv.01803002

Saueressig TM, Barros AT. Diagnóstico da susceptibilidade de populaçôes da mosca-dos-chifres a inseticidas em Goiás, Tocantins e Distrito Federal. Planaltina: Embrapa Cerrados; 2003. 16 p. (Embrapa Cerrados, Boletim de Pesquisa e Desenvolvimento, n. 82). [cited 2011 Nov. 02]. Available from: www.cpac.embrapa.br/baixar/90/t.

Scott FB, Coumendouros K, Grisi L. Avaliação in vitro da suceptibilidade da Haematobia irritans a alguns inseticidas no estado de São Paulo. Rev Bras Parasitol Vet 1994; 3(2): 83-85.

Sheppard DC, Hinkle NC. A field procedure using disposable materials to evaluate horn fly insecticide resistance. J Agric Entomol 1987; 4(1): 87-89. 
Sheppard DC, Joyce JA. High levels of pyrethroid resistance in horn flies (Diptera: Muscidae) selected with cyhalothrin. J Econ Entomol 1992; 85(5): 1587-1593. PMid:1401477.

Sheppard DC, Marchiondo AA Toxicity of diazinon to pyrethroid resistant and susceptible horn flies, Haematobia irritans (L.): laboratory studies and field trials. J Agric Entomol 1987; 4(3): 262-270.
Steelman CD, McNew RW, Brown MA, Tolley G, Phillips JM. Efficacy of Brahman breeding in the management of insecticide-resistant horn flies (Diptera: Muscidae) on beef cattle. J Econ Entomol 1994; 87(1): 7-14. PMid:8144749.

Valério JR, Guimarães JH. Sobre a ocorrência de uma nova praga, Haematobia irritans (L.) (Diptera, Muscidae), no Brasil. Rev Bras Zool 1983; 1(4): 417-418. 